\title{
Selective foraging by non-native rainbow trout on invertebrates in Patagonian streams in Argentina
}

\author{
Cecilia Yanina Di Prinzio ${ }^{1,2,3^{*}}$, Guillermo Omad ${ }^{1,2,3}$, María Laura Miserendino ${ }^{1,2,3}$ and Ricardo Casaux $x^{1,2,3,4}$
}

\begin{abstract}
Background: It is well known that fish predation alters ecosystem processes by top-down effects. Salmonids are described as aggressive, visually and size-selective predators. Thus, prey selection by the non-native rainbow trout was examined on a seasonal basis at two streams: Nant y Fall (NyF) and Cabeza de Vaca (CVA) at Patagonia, a region where this kind of information is lacking.

Results: The benthos density at NyF was higher than that at CVA, and at both streams, riffles supported higher macroinvertebrate densities than pools. The diet of trouts from both streams was dominated by aquatic macroinvertebrates, was diverse, and was varied seasonally. The individuals represented in the stomach contents were among the largest available at the streams. Diet diversity peaked during spring at NyF and during summer at CVA, whereas at both streams, the niche width peaked during spring.

Prey selectivity varied seasonally. The selected preys included both aquatic (Gasteropoda, Crustacea, Plecoptera, Trichoptera, Ephemeroptera, Coleoptera, Diptera, and Odonata) and terrestrial organisms (adult dipterans,

Oligochaeta, Araneae, Homoptera, Hymenoptera, Orthoptera, and Hemiptera). Some infaunal invertebrates like oligochaetes and some small Coleoptera and Diptera larvae (mainly Chironomidae) were not selected by trouts.

Conclusions: Despite of the overall dominance of trichopteran species, the composition of the diet of the rainbow trout varied seasonally. This fish positively selected both aquatic and terrestrial organisms. We observed that in both streams, trouts consumed the larger individuals available in those environments.
\end{abstract}

Keywords: Selective predation; Non-native fish; Stream; Patagonia

\section{Background}

In freshwater environments, fish predation is considered an important selective force because it can shape the structure and composition of freshwater communities by top-down effects determining food web functioning and dynamics (Newman and Waters 1984; Nakano et al. 1999; Baxter et al. 2004; Wesner 2012).

It has been suggested that in order to increase fitness, predators actively choose prey that minimizes energy spent on capturing and handling while maximizing energy intake (Stephens and Krebs 1986). Consequently, understanding on the predator-prey relationships is one of the most important issues to comprehend the trophic

\footnotetext{
* Correspondence: cydiprinzio@yahoo.com.ar

${ }^{1}$ Consejo Nacional de Investigación en Ciencia y Tecnología (CONICET),

Rivadavia 1917, 1033 Buenos Aires, Argentina

${ }^{2}$ Centro de Investigaciones Esquel de Montaña y Estepa Patagónica (CIEMEP),

Sarmiento 890, 9200 Esquel, Argentina

Full list of author information is available at the end of the article
}

interactions and their effects (Macchi et al. 1999). Worldwide, many studies have attempted to determine the mechanisms of prey selection by salmonids in streams, linking the composition of diets with available drifting prey (Allan 1978; Bisson 1978; Ringler 1979; Forrester et al. 1994; Nakano et al. 1999). Those studies demonstrated the selection of different prey taxa and size. Zaret (1980) and Peckarsky (1982) stated that selective predation on a particular prey size altered the structure of invertebrate communities. In different works, Sih (1987) and Wooster (1994) proposed that predators produce a strong selective force that is concentrated on vulnerable individuals, and this selection pressure can lead to changes in the behavior, growth, fecundity, and morphology of susceptible prey. To enhance recreational fishing, Patagonian streams have been affected by the introduction of salmonids since the early twentieth century. The rainbow trout (Oncorhynchus mykiss) has been the most widely distributed species in the region (Pascual et al. 2002; Baigun and 
Ferriz 2003; Di Prinzio et al. 2009) generating a great economic resource input. Several studies focused on rainbow trouts' feeding strategies in Patagonian environments and analyzed the impact of this species on native fauna (Modenutti and Balseiro 1994; Pascual et al. 2002; Buria et al. 2007, 2009, 2010; Albariño and Buria 2011; Di Prinzio and Casaux 2012; Di Prinzio et al. 2013). However, the degree of prey selectivity displayed by this fish remains poorly understood.

Prey selectivity metrics are important measures of possible impacts on native communities and of changes to stream environments (Wooster 1994; Osenberg et al. 1996, 1999; Johnson et al. 2006). Therefore, we investigated in a seasonal basis prey selection by the rainbow trout at two streams in Patagonia.

\section{Methods}

\section{Study area and site selection}

The study area is located in the Northwest of the Chubut Province, Patagonia, Argentina, in the ecotone between the Subantarctic forest and the Patagonian steppe, and exhibits a marked altitudinal gradient $(2,000$ to $600 \mathrm{~m}$ above sea level (m.a.s.l.)). Perennial (Austrocedrus chilensis, Nothofagus dombeyi, and Maitenus boaria) and deciduous (Nothofagus pumilio and Nothofagus anctarctica) tree species constitute the Subantarctic forest. Rivers at the study area have a pluvionival regime; therefore, discharge pattern is bimodal, with one peak associated to winter rains (June to July) and a second one originated by snowmelt in spring (September to October) (Coronato and del Valle 1988). The watercourses selected for this study were Nant y Fall (NyF) and Cabeza de Vaca (CVA) streams (2nd order streams). The sampled site at NyF (43 $13^{\prime} 24^{\prime \prime} \mathrm{S}$, $\left.71^{\circ} 25^{\prime} 17^{\prime \prime} \mathrm{W}\right)$ is located $3.7 \mathrm{~km}$ downstream of Rosario lake $\left(19 \mathrm{~km}^{2}\right)$ in the Futaleufú-Yelcho basin, at an altitude of 690 m.a.s.l. NyF's sub-basin has $15 \%$ of the area dedicated to pastures, $24.8 \%$ correspond to lakes, and $60.2 \%$ to the timberland ( $\mathrm{H}$. Claveri unpublished information). Land-use adjacent to the lake and the stream is mainly pasture, with agricultural and extensive livestock grazing activity.

The sampled site selected at CVA (740 m.a.s.l.) (43 $30^{\prime} 02^{\prime \prime} \mathrm{S}, 71^{\circ} 20^{\prime} 49^{\prime \prime} \mathrm{W}$ ) is located $25.8 \mathrm{~km}$ from the headwater and belongs to the Carrenleufú basin. CVA's sub-basin is covered by pastures (29.4\%) and timberland $(65.4 \%)$, and $5.2 \%$ of the area corresponds to lakes (H. Claveri unpublished information). Land-use around the stream is primarily wood extraction.

\section{Environmental characterization and sampling procedure}

Sampling sites were visited in early autumn (May), late winter (September), and late spring (December) of 2005 and during late summer (March) of 2006, under stable environmental conditions. At each site, substrate size composition was estimated as percentages of boulders, cobbles, gravel, pebbles, and sand in the reach, using a $1-\mathrm{m}^{2}$ grid $(n=3)$. Digital pictures of the grid were obtained and processed in the laboratory. Water velocity $\left(\mathrm{ms}^{-1}\right)$ was measured in mid-channel (thalweg) on three occasions by timing a float (average of three trials) as it moved over a distance of $10 \mathrm{~m}$ (Gordon et al. 1994). Average depth $(\mathrm{cm})$ was estimated from five measurements along one transversal profile across the channel with a calibrated stick. At each site (run-riffle areas), water temperature $\left({ }^{\circ} \mathrm{C}\right)$ was measured with a mercury thermometer.

During each sampling, specific conductance $\left(\mu \mathrm{S}_{20} \mathrm{~cm}^{-1}\right)$, $\mathrm{pH}$, and dissolved oxygen ( $\mathrm{DO}, \mathrm{mg} \mathrm{O}_{2} \mathrm{l}^{-1}$ ) were measured with a multiparameter probe (Hach sensION 156, Hach Instruments, Lovedale, CO, USA). For nutrient analyses, water samples were collected below the water surface and kept at $4{ }^{\circ} \mathrm{C}$ prior to analysis and transported to the laboratory. Total suspended solids (TSS), nitrate + nitrite nitrogen $\left(\mathrm{NO}_{3}+\mathrm{NO}_{2}\right)$, ammonia $\left(\mathrm{NH}_{4}\right)$, and soluble reactive phosphate (SRP) were analyzed following standard methods (APHA 1994).

\section{Biological data collection}

Fish and macroinvertebrates were sampled seasonally at the four mentioned dates. Fish were sampled along reaches of $100 \mathrm{~m}$ long employing a portable backpack electrofishing gear (Coffelt Mark-10 CPS, output $350 \mathrm{~V}$ ). The width of the sampling area was coincident with the stream width. In situ, the individuals caught were preserved in cooled containers. At laboratory, fish were counted, weighted $(\mathrm{g})$, and measured in total length $(\mathrm{cm})$ and the stomachs were separated and fixed with $90 \%$ alcohol for posterior diet analysis.

Macroinvertebrate samples were obtained using a Surber sampler $\left(0.09 \mathrm{~m}^{2} ; 250-\mathrm{mm}\right.$ mesh size $)$. Three samples from riffles $(n=3)$ and three from pools $(n=3)$ were taken at each reach. Samples were fixed in situ with $4 \%$ formaldehyde for posterior analysis.

At the laboratory, all the invertebrates represented in the samples, both in fish stomach contents and in benthos samples, were sorted (using a binocular microscope at $\times 5$ magnification), identified to the lowest taxonomic level possible using available keys (Domínguez and Fernández 2009) and counted. Individuals from stomach and benthos samples were identified to the same taxonomic level. Terrestrial invertebrates (including those adults of aquatic insects with aerial phases) in the stomach contents were grouped into a single category (terrestrial items). Algae and vegetal fragments were grouped into a single category (vegetal items). Inorganic material (i.e., little stones) was classified as inorganic items. Total body length of each individual, excluding antennae and terminal cerci, was measured to the nearest $0.1 \mathrm{~mm}$ using an ocular 
micrometer (Zeiss stereomicroscope Stemi DV4, Zeiss, Jena, Germany).

\section{Data analysis}

In order to calculate the contribution of a food item to the diet, the dietary coefficient $(Q)$ (Hureau 1970) was employed. This method reduces the biases associated to the use of numeric or weight methods, because it is the product of the percentage by number $(\% F)$ and the percentage by mass $(\% M)$ of each prey type $(Q=\% F \times \% M)$. According to this index, the prey items were separated into the following categories: main preys, $Q>$ 200 ; secondary preys, $200>Q>20$; and occasional preys, $Q<20$.

To estimate diet width, the Levins (1968) index was calculated with $95 \%$ confidence limits as follows: $B=1$ / $\Sigma p^{2}{ }_{i}, i=1 \ldots n$, where $p_{i}$ is the proportion of each prey type $i$ in the diet and equals $A i$ expressed as fraction rather than percentage.

Diet diversity was assessed using the Shannon-Wiener index of diversity (Krebs 1989) according to:

$$
H=-\sum_{i=l}^{s}\left(p_{i} \ln p_{i}\right)
$$

where $p_{i}$ is the fraction of items in benthos sample that are of category $i$.

Comparisons between proportions of preys in the rainbow trout stomach contents and in benthos samples were carried out using Ivlev's index. Ivlev (1961) electivity index $(E i)$ was selected because it handles the situation where a prey item is represented in the diet but absent from field samples or where an item occurs in the field but is absent from the stomach contents. The electivity index ranges between 1 (the prey is represented in the stomachs but absent from benthos samples) and -1 (the prey is absent from the stomach but present in benthos samples) as it is estimated according to the following equation:

$$
\mathbf{I}=\frac{E i-B i}{E i+B i}
$$

where $E i$ is the percentage by number of taxon $i$ in the stomach contents and $B i$ is the percentage by number of taxon $i$ in benthos samples. Additionally, to identify if trouts select preys according to their size, the Ivlev's electivity index was calculated for three size ranges of each prey species (small, medium, and large size).

Table 1 Physico-chemical parameters, annual mean standard deviation, and total range values from NyF and CVA

\begin{tabular}{|c|c|c|c|c|}
\hline & NyF & & CVA & \\
\hline Physical parameters & Mean \pm SD & Range & Mean \pm SD & Range \\
\hline Water temperature $\left({ }^{\circ} \mathrm{C}\right)$ & $10.4 \pm 2.7$ & 7.6 to 13.6 & $6.5 \pm 2.4$ & 4.0 to 9.4 \\
\hline Wet width (m) & $21.1 \pm 3.1$ & 17.5 to 25.0 & $7.2 \pm 2.9$ & 4.6 to 11.0 \\
\hline Depth (m) & $0.2 \pm 0.1$ & 0.19 to 0.32 & $0.2 \pm 0.0$ & 0.20 to 0.28 \\
\hline Water velocity $\left(\mathrm{ms}^{-1}\right)$ & $0.8 \pm 0.2$ & 0.68 to 1.0 & $1.1 \pm 0.2$ & 0.93 to 1.15 \\
\hline Discharge $\left(\mathrm{m}^{3} \mathrm{~s}^{-1}\right)$ & $4.6 \pm 2.4$ & 2.71 to 8.0 & $1.9 \pm 0.9$ & 0.92 to 3.08 \\
\hline \multicolumn{5}{|l|}{ Substrate composition (\%) } \\
\hline Boulder & 20 & & 15 & \\
\hline Cobble & 25 & & 30 & \\
\hline Pebble & 10 & & 15 & \\
\hline Gravel & 30 & & 25 & \\
\hline Sand & 15 & & 15 & \\
\hline Chemical parameters & Mean $\pm S D$ & Range & Mean $\pm S D$ & Range \\
\hline Conductivity $\left(\mu \mathrm{S} \mathrm{cm}^{-1}\right)$ & $114.0 \pm 2.7$ & 112.0 to 118.0 & $50.0 \pm 14.0$ & 38.0 to 63.0 \\
\hline Dissolved oxygen $\left(\mathrm{mg} \mathrm{l}^{-1}\right)$ & $8.8 \pm 1.6$ & 7.7 to 11.1 & $11.1 \pm 1.7$ & 9.7 to 13.0 \\
\hline $\mathrm{pH}$ & $7.6 \pm 0.4$ & 7.2 to 7.9 & $7.3 \pm 0.1$ & 7.1 to 7.4 \\
\hline Turbidity (TNU) & $4.2 \pm 3.9$ & 2.0 to 10.0 & $10.0 \pm 15.0$ & 0 to 27.0 \\
\hline Ammonium $\left(\mu g L^{-1}\right)$ & $1.05 \pm 0.5$ & 0.6 to 1.6 & $0.86 \pm 0.7$ & 0 to 1.7 \\
\hline Nitrate + nitrite nitrogen $\left(\mu \mathrm{g} \mathrm{L}^{-1}\right)$ & $0.18 \pm 0.2$ & 0.1 to 0.3 & $0.17 \pm 0.2$ & 0 to 0.3 \\
\hline Soluble reactive phosphate $\left(\mu \mathrm{g} \mathrm{L}^{-1}\right)$ & $0.37 \pm 0.0$ & 0.3 to 0.4 & $0.53 \pm 0.2$ & 0.2 to 0.7 \\
\hline Total suspended solids $\left(\mathrm{mg} \mathrm{L}^{-1}\right)$ & $2.74 \pm 0.8$ & 1.7 to 3.6 & $2.38 \pm 1.8$ & 0.7 to 4.4 \\
\hline
\end{tabular}
streams (Patagonia, Argentina)

During the study period (early autumn, late winter, late spring of 2005, and late summer of 2006). SD, standard deviation. 
To identify differences in prey availability and density between streams, habitats, and seasons, we employed one-way analysis of variance. Similarly, to identify seasonal changes in the size of macroinvertebrates from the benthos, we used ANOVA and the post hoc NewmanKeuls test (Sokal and Rohlf 1995). Prior to analysis data were tested for normality and homogeneity of variances using Kolmogorov-Smirnov and Levene's tests, respectively, and $\log (x+1)$-transformed when appropriate (Gotelli and Ellison 2005). Mann-Whitney test was used to verify whether the length distributions between individuals represented in stomach contents and in benthos samples were different (Sokal and Rohlf 1995).

To compare the size of rainbow trouts between streams, a Kruskal-Wallis test was applied (Sokal and Rohlf 1995).

In order to summarize the variation among seasons in the distribution of fish based on their diets, we performed a Non-Metric Multidimensional Scaling (N-MDS) ordination technique based on the Bray-Curtis similarity coefficient using the software Statistica (version 6.0) (Ludwing and Reynolds 1988; Marshall and Elliott 1997; Clarke and Warwick 1994). Pearson correlation matrices based on quantitative data of trout stomach contents were built for each stream ( $\mathrm{NyF}$ and $\mathrm{CVA})$. The proximity of points in a resulting 2-D plot graphic indicates a higher degree of similarity, whereas more dissimilar points are positioned further apart.

\section{Results}

\section{Environmental features}

At both sites, the substrate was dominated by gravel cobble (Table 1). The highest value of water temperature (late summer), wet width (late spring), depth (late spring), current speed (late spring), and discharge (late spring) was observed at $\mathrm{NyF}$ while the highest value of dissolved oxygen (late summer) and turbidity (late winter) was recorded at CVA (Table 1). Physicochemical conditions indicated that waters were circum-neutral and well oxygenated. Conductivity was significantly higher (Kruskal-Wallis, $p<0.05)$ at NyF than at CVA. Both streams presented similar (Kruskal-Wallis, $p>0.05$ ) low nutrient levels as expected for low-order streams in mountain areas (Table 1).

\section{Biological features}

Macroinvertebrate density was higher at $\mathrm{NyF}$ than at CVA (ANOVA, $p<0.05$ ); nevertheless, the seasonal trend in benthos density at both streams was similar (ANOVA, $p>0.05$ ). At both streams, riffles supported higher macroinvertebrate densities than pools (ANOVA, $p<0.05$ ), being Diptera at CVA and Trichoptera at NyF the most abundant groups (Figure 1).

Overall, at both streams, the benthos community was mainly composed of individuals belonging to small size classes (Figure 2). However, the size of the individuals changed seasonally (ANOVA, $p<0.05$ ), and at both

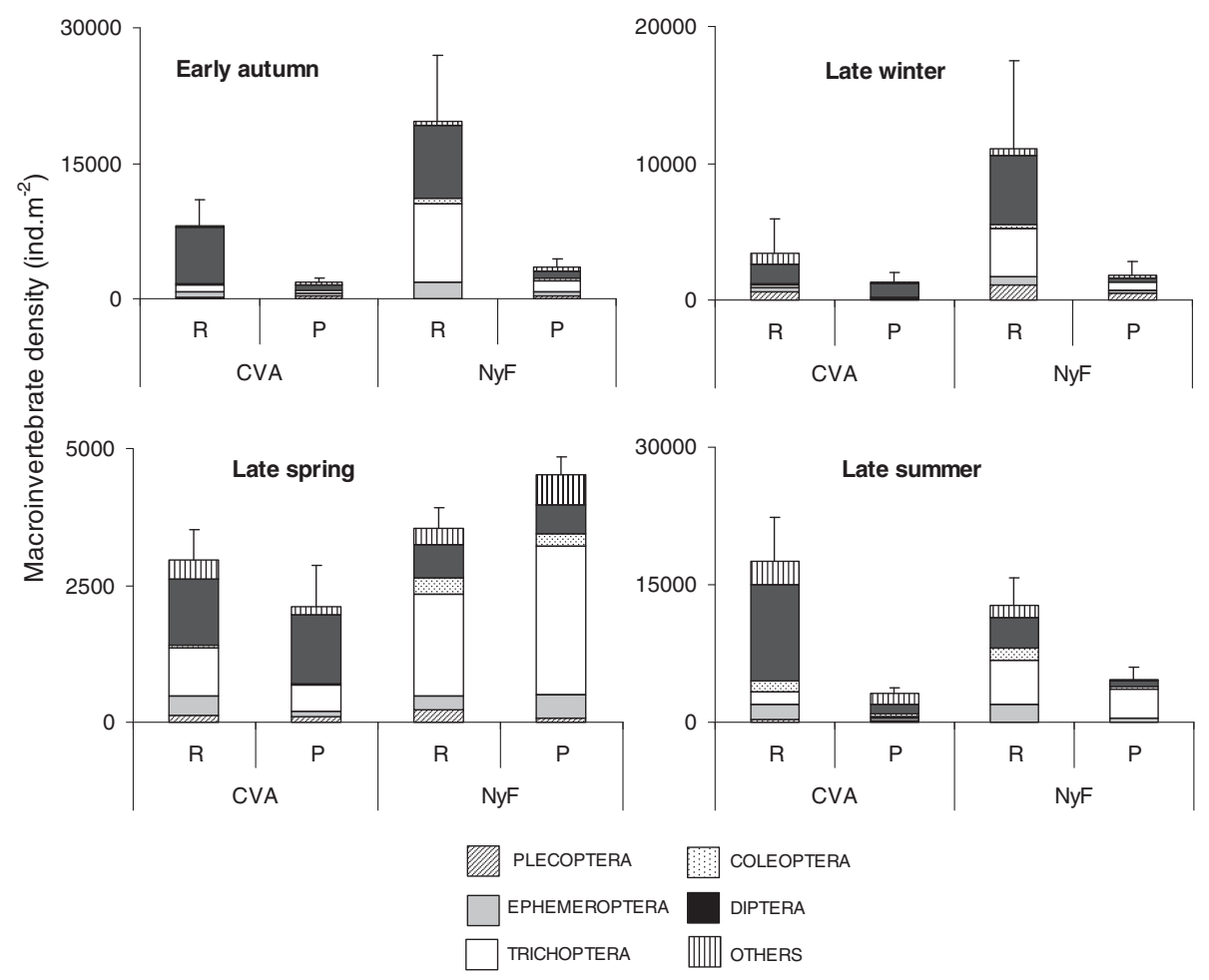

Figure 1 Mean invertebrate density (major groups) $\left( \pm\right.$ SD, ind $\mathbf{~ m}^{2}$ ) by season. At riffles $(R)$ and pools $(P)(n=3)$ of Cabeza de Vaca (CVA) and Nant y Fall (NyF) streams (Patagonia, Argentina) from May 2005 (early autumn) to March 2006 (late summer). 


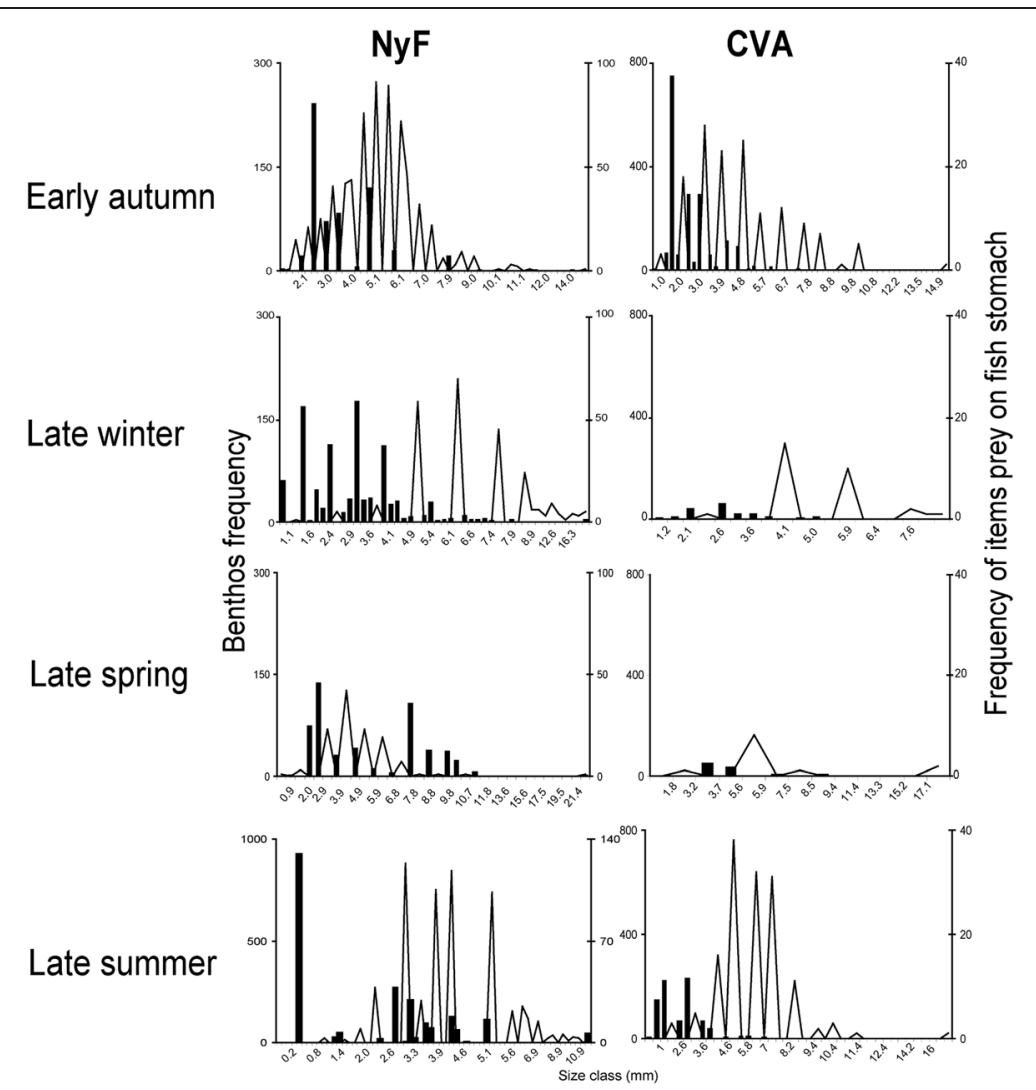

Figure 2 Frequency distribution of size classes. Macroinvertebrates in the environment (bars) and in rainbow trout (Oncorhynchus mykiss) stomach contents (line) at Nant y Fall (NyF) and Cabeza de Vaca (CVA) streams (Patagonia Argentina) during the study period (early autumn, late winter, late spring 2005, and late summer 2006).

streams, the larger individuals were observed during late spring (Newman-Keuls test, $p<0.05)$.

A total of 109 and 60 rainbow trouts were caught throughout the study period at NyF and CVA, respectively. Trouts from both streams were similar in total length and mass when comparing mean values (Kruskal-Wallis, $p>0.05$ ) (Table 2). The high biomass value observed in $\mathrm{NyF}(988.7 \mathrm{~g})$ corresponded just to one specimen. The diet of trouts from both streams was dominated by aquatic macroinvertebrates (Figure 3) and was diverse, and distinct preys were dominant in different seasons. In NyF crustaceans (Hyalella araucana) and trichopterans (Parasericostoma ovale and Hudsonema flaminii) conformed the diet almost the whole year; plecopteran preys appeared in the trout diet in spring at CVA (Figure 3). During early autumn and late summer, trouts from $\mathrm{NyF}$ foraged predominantly on $P$. ovale (Figure 2 ) which was the most abundant species in benthos samples (Additional file 1). Trouts from CVA preyed predominantly on the most abundant benthos species Brachysetodes sp., (see Additional file 1) in late spring and summer (Figure 2). During the remaining seasons, the main
Table 2 Morphometric measurements annual mean and total range values, seasonal niche broad, and seasonal prey diversity

\begin{tabular}{|c|c|c|c|c|}
\hline \multirow[b]{2}{*}{$\begin{array}{l}\text { Biological } \\
\text { parameters }\end{array}$} & \multicolumn{2}{|l|}{ NyF $(n=109)$} & \multicolumn{2}{|c|}{ CVA $(n=60)$} \\
\hline & Mean $\pm S D$ & Range & Mean \pm SD & Range \\
\hline Fish length $(\mathrm{cm})$ & $11.1 \pm 7.0$ & 2.6 to 44.2 & $11.3 \pm 4.2$ & 5.2 to 9.6 \\
\hline Fish weight (g) & $44.6 \pm 157.0$ & 0.1 to 988.7 & $20.3 \pm 21.2$ & 1.6 to 84.7 \\
\hline Diet broad & \multicolumn{4}{|l|}{ Levin's index } \\
\hline Early autumn & \multicolumn{2}{|l|}{0.032} & \multicolumn{2}{|l|}{0.263} \\
\hline Late winter & \multicolumn{2}{|l|}{0.247} & \multicolumn{2}{|l|}{0.169} \\
\hline Late spring & \multicolumn{2}{|l|}{0.331} & \multicolumn{2}{|l|}{0.588} \\
\hline Late summer & \multicolumn{2}{|l|}{0.037} & \multicolumn{2}{|l|}{0.332} \\
\hline Prey diversity & \multicolumn{2}{|c|}{ Shannon index } & & \\
\hline Early autumn & \multicolumn{2}{|l|}{1.82} & \multicolumn{2}{|l|}{3.37} \\
\hline Late winter & \multicolumn{2}{|l|}{3.44} & \multicolumn{2}{|l|}{1.98} \\
\hline Late spring & \multicolumn{2}{|l|}{3.54} & \multicolumn{2}{|l|}{1.98} \\
\hline Late summer & \multicolumn{2}{|l|}{1.25} & \multicolumn{2}{|l|}{3.46} \\
\hline
\end{tabular}

Of Oncorhynchus mykiss (rainbow trout) from Nant y Fall (NyF) and Cabeza de Vaca (CVA) streams (Patagonia, Argentina) during the study period (early autumn, later winter, later spring of 2005, and later summer of 2006). 


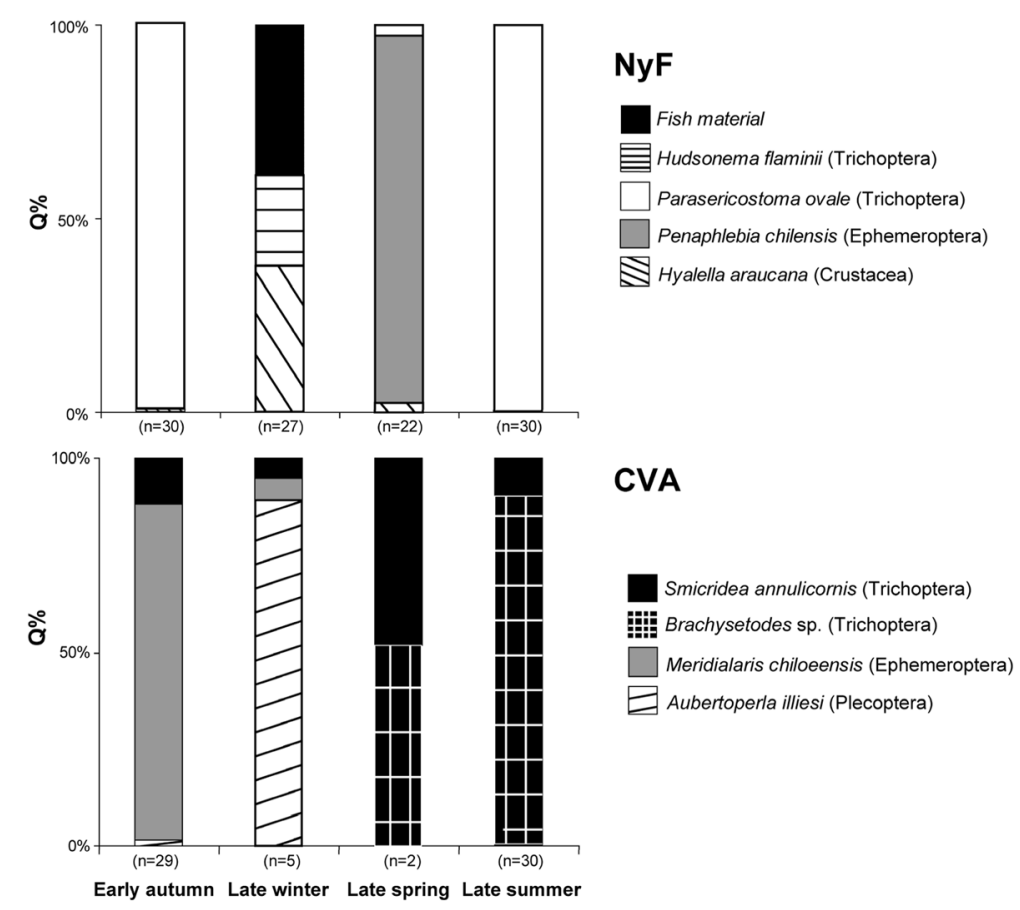

Figure 3 Diet composition (dietary coefficient Q\%). Oncorhynchus mykiss at Nant y Fall (NyF) and Cabeza de Vaca (CVA) streams (Patagonia Argentina) during the study period (early autumn, late winter, late spring 2005, and late summer 2006); n, number of fish stomach analyzed.

species in the diet were invertebrates scarcely represented in benthos samples (i.e., $H$. araucana in late winter at $\mathrm{NyF}$ and Aubertoperla illiesi in late winter at CVA) (see Additional file 1).

The individuals represented in the stomach contents $(\mathrm{NyF} \overline{\mathrm{x}}=4.9 \pm 2.2 \mathrm{~mm} ; \mathrm{CVA} \overline{\mathrm{x}}=5.0 \pm 2.1 \mathrm{~mm})$ were among the largest available at the streams $(\mathrm{NyF} \overline{\mathrm{x}}=2.9 \pm 2.1 \mathrm{~mm}$; CVA $\bar{x}=2.5 \pm 1.4 \mathrm{~mm}$ ). The prey size consumption at $\mathrm{NyF}$ did not show any evident pattern (Figure 4), whereas trouts at CVA consumed the larger individuals of all prey species along the year (Figure 5).

At $\mathrm{NyF}\left(H^{\prime}=3.54\right)$ and CVA $\left(H^{\prime}=3.46\right)$, diet diversity peaked during late spring and late summer, respectively, whereas at both streams, the niche width peaked during late spring (Table 2).

The Ivlev index indicated that at $\mathrm{NyF}$, the Ephemeroptera Meridialaris chiloeensis (early autumn and late spring), the Trichoptera Oxyethira bidentata (early autumn, late winter, and summer), the Diptera Thienemanniella sp. (early autumn), the Gasteropoda Biomphalaria peregrina (late summer), and the fish eggs were positively selected by rainbow trouts (Table 3 ). The species positively selected at CVA were the Plecoptera A. illiesi (early autumn), the Coleoptera Stethelmis kaszabi (early autumn and late summer), Muscidae larvae (early autumn, late winter, and late spring), and the Ephemeroptera Nousia crena (early autumn) (Table 3). Although present and abundant in the benthos throughout the year at both streams, some
Oligochaeta (Lumbriculidae spp.), Trichoptera (Smicridea frequens and Neoatopsyche brevispina), Coleoptera (Luchoelmis cekalovici and Austrolimnius sp.), and Diptera (Empididae larvae, Parapsectocladius sp., Pseudochironomus sp., and Ceratopogonidae sp.) species were scarcely or not selected by trouts (Table 3). Terrestrial preys like Arachnidae, adult dipterans, Hymenoptera, Homoptera, Hemiptera, and Isopoda were positively selected by the rainbow trout at both streams (Table 3). At both streams, trouts selected prey items with body size ranging from medium to large (Table 4). In this sense, while at NyF, the larger prey items of Ephemeroptera: $N$. crena (early autumn) and Andesiops torrens (later summer); Plecoptera: N. femina (early autumn), A. illiesi, and L. jaffuelli (late winter and late spring); Trichoptera: Brachysetodes sp. (early autumn), Smicridea annulicornis (early autumn and late summer), and $P$. ovale (late winter and late spring); and Diptera: Simuliidae (early autumn and late winter) were selected, and at CVA, the larger prey items of Ephemeroptera: N. crena (late summer); Plecoptera: Antarctoperla michaelseni (early autumn); Trichoptera: S. annulicornis (early autumn and late summer), and Diptera: Paratrichocladius (late winter) were chosen.

The results of the MDS ordination supported data displayed in Figure 3 (Figure 6). At NyF, most of the trout captured during autumn and summer (stomachs dominated by $P$. ovale) were grouped to the negative 


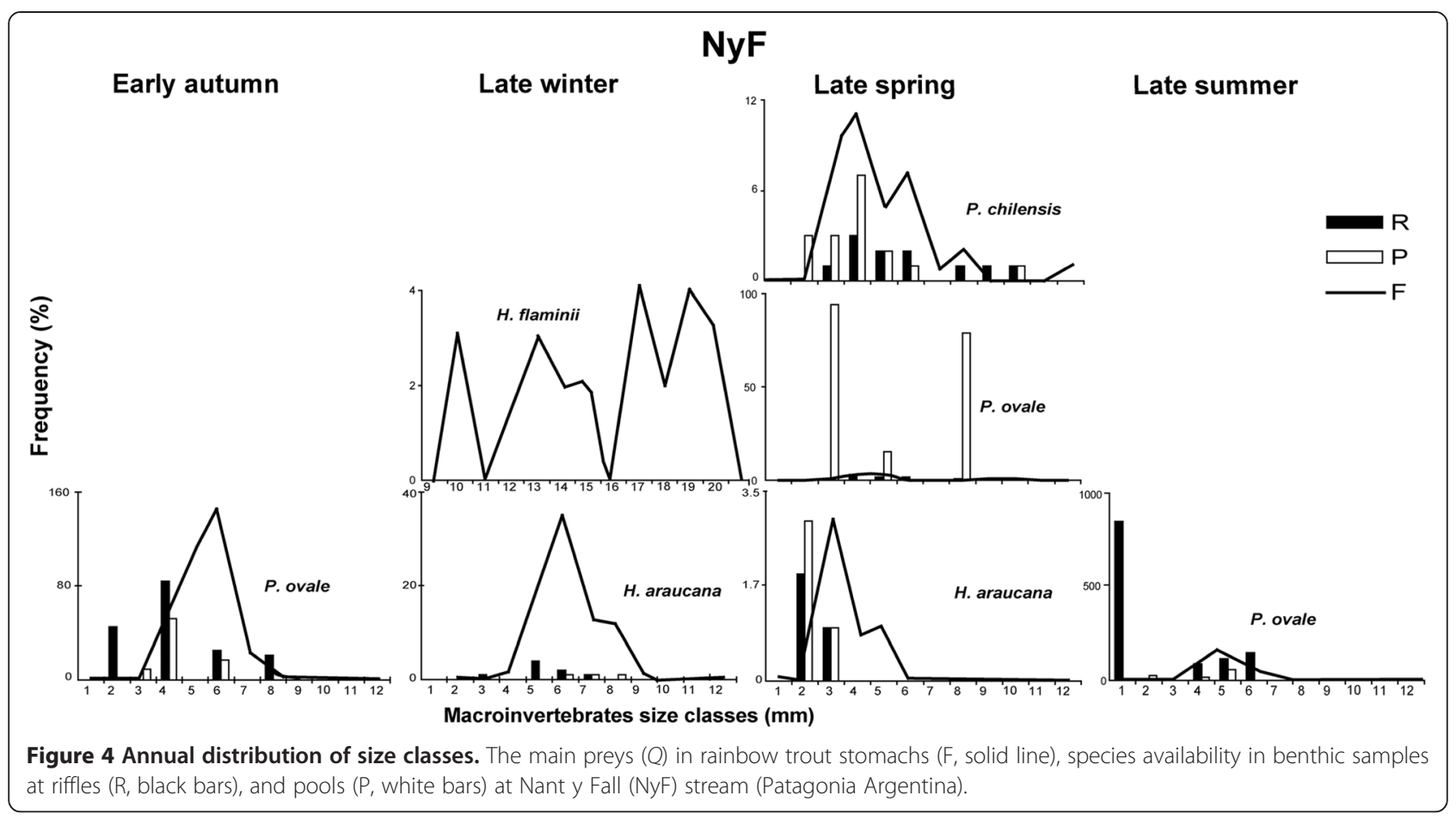

end of dimension 1, whereas those obtained during spring (stomachs dominated by Penaphlebia chilensis) were positioned on the lower right quadrant and those captured on winter (stomach content: fish material, $H$. flaminii and $H$. araucana) were mainly grouped to the positive side of dimension 2 (Figure 6). On the other hand, at CVA, the MDS ordination reflected that trout captured during summer was grouped towards the positive side of dimension 1. Dominant preys at this season were Brachysetodes sp. and S. annulicornis (Figure 6).

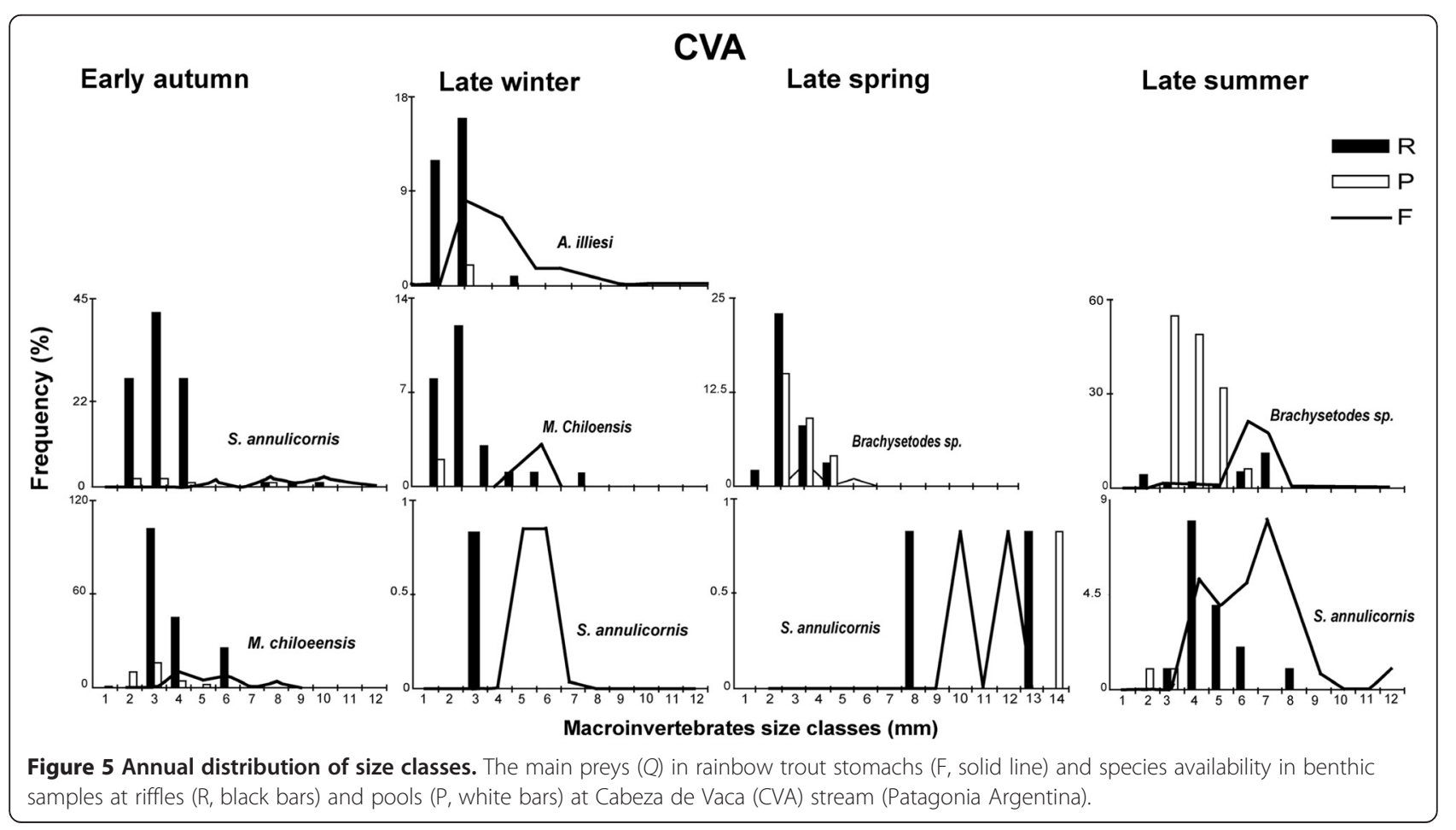


Table 3 Selectivity index (Ivlev) of prey in the diet of rainbow trout (Oncorhynchus mykiss)

\begin{tabular}{|c|c|c|c|c|c|c|c|c|c|}
\hline \multirow[b]{2}{*}{ Order } & \multirow[b]{2}{*}{ Species } & \multicolumn{2}{|c|}{ Early autumn } & \multicolumn{2}{|c|}{ Late winter } & \multicolumn{2}{|c|}{ Late spring } & \multicolumn{2}{|c|}{ Late summer } \\
\hline & & NyF & CVA & NyF & CVA & $\mathrm{NyF}$ & CVA & NyF & CVA \\
\hline Oligochaeta & Lumbriculidae sp.* & -1 & -1 & -1 & -1 & -1 & -1 & -1 & -1 \\
\hline \multirow[t]{2}{*}{ Gasteropoda } & Chilina patagonica & 0.11 & 0.91 & -1 & -- & -1 & 0.95 & -1 & 0.41 \\
\hline & Biomphalaria peregrina & --- & --- & --- & --- & --- & --- & 1 & --- \\
\hline \multirow[t]{2}{*}{ Crustacea } & Hyalella araucana & 0.75 & --- & 0.98 & --- & 0.31 & --- & 1 & --- \\
\hline & Isopoda* & --- & 1 & --- & --- & & --- & --- & --- \\
\hline Araneae & Arachnidae* & --- & --- & 1 & --- & 1 & --- & --- & --- \\
\hline Cladocera & Daphnia daphnia & --- & --- & 1 & --- & --- & --- & --- & --- \\
\hline \multirow[t]{8}{*}{ Plecoptera } & Aubertoperla illiesi & --- & 1 & -0.30 & 0.71 & -- & -1 & --- & -1 \\
\hline & Limnoperla jaffuelli & -1 & --- & -0.20 & -1 & 0.57 & -1 & --- & --- \\
\hline & Antarctoperla michaelseni & -1 & 0.12 & --- & -1 & -1 & -1 & -1 & 0.76 \\
\hline & Notoperlopsis femina & -0.70 & 1 & -1 & --- & --- & --- & -1 & -1 \\
\hline & Pelurgoperla personata & --- & 0.95 & --- & -1 & --- & -1 & --- & 0.93 \\
\hline & Potamoperla myrmidon & --- & --- & --- & --- & --- & --- & --- & 1 \\
\hline & Udamocercia arumifera & --- & --- & --- & --- & --- & -1 & --- & 1 \\
\hline & Adult* & --- & --- & --- & -- & 1 & --- & -- & --- \\
\hline \multirow[t]{10}{*}{ Ephemeroptera } & Nousia crena & 0.41 & -1 & --- & -1 & -1 & -1 & -1 & 0.85 \\
\hline & Meridialaris chiloeensis & 1 & 0.64 & -1 & 0.73 & 1 & --- & --- & -1 \\
\hline & Meridialaris laminata & -1 & --- & 1 & --- & -1 & -1 & --- & --- \\
\hline & Penaphlebia chilensis & -1 & -1 & -0.30 & --- & 0.74 & -1 & -1 & 1 \\
\hline & Penaphlebia flavidula & --- & --- & 1 & --- & --- & --- & --- & --- \\
\hline & Penaphlebia $(A)^{*}$ & --- & --- & --- & -- & 1 & --- & --- & --- \\
\hline & Andesiops torrens & 0.35 & 0.78 & -1 & -- & -1 & -1 & 0.34 & 0.03 \\
\hline & Andesiops ardua & -0.90 & -1 & -1 & -1 & 1 & -1 & -1 & -1 \\
\hline & Ephemeroptera sp. & 1 & --- & --- & --- & 1 & --- & --- & --- \\
\hline & Parasericostoma ovale & 0.38 & 0.96 & -0.80 & -1 & -0.70 & 1 & 0.48 & 1 \\
\hline \multirow[t]{12}{*}{ Trichoptera } & Hudsonema flaminii & 0.50 & 0.72 & 1 & -1 & -1 & -1 & --- & 0.89 \\
\hline & Brachysetodes sp. & -0.30 & 0.46 & -1 & -1 & -1 & 0.14 & -1 & 0.94 \\
\hline & Triplectides sp. & --- & -1 & 1 & -- & -- & -1 & --- & -1 \\
\hline & Oxyethira bidentata & 1 & --- & 1 & --- & -1 & --- & 1 & --- \\
\hline & Neoatopsyche unispina & -1 & 0.97 & -1 & -1 & 1 & -1 & -1 & -1 \\
\hline & Neoatopsyche brevispina & -1 & -1 & -1 & --- & -- & --- & -1 & 0.14 \\
\hline & Cailloma sp. & 1 & -1 & -1 & --- & -- & --- & -1 & 0.93 \\
\hline & Smicridea annulicornis & 0.45 & 0.04 & -1 & 0.90 & 0.53 & 0.90 & -0.60 & 0.64 \\
\hline & Smicridea frequens & -1 & -1 & -1 & --- & --- & --- & -1 & --- \\
\hline & Limnephilidae & --- & --- & 1 & --- & -- & --- & --- & --- \\
\hline & Adult* & --- & --- & --- & --- & 1 & --- & --- & --- \\
\hline & Stethelmis kaszabi & 1 & 1 & -1 & --- & -1 & --- & -1 & 1 \\
\hline \multirow[t]{5}{*}{ Coleoptera } & Luchoelmis sp. & -1 & 1 & -1 & -1 & -1 & -1 & -1 & -1 \\
\hline & Elmidae (L) & -1 & -1 & --- & 1 & -1 & -1 & -1 & -1 \\
\hline & Luchoelmis cekalovici & -1 & -1 & -1 & -1 & -1 & -1 & -1 & -1 \\
\hline & Austrolimnius sp. & -1 & -1 & -1 & -1 & -- & -1 & -1 & -1 \\
\hline & Rhantus signatus & --- & -- & --- & --- & --- & --- & 1 & --- \\
\hline
\end{tabular}


Table 3 Selectivity index (Ivlev) of prey in the diet of rainbow trout (Oncorhynchus mykiss)

\begin{tabular}{|c|c|c|c|c|c|c|c|c|c|}
\hline & Tropisternus setiger & -- & -- & -- & --- & -- & $\overline{---}$ & 1 & $\overline{---}$ \\
\hline & Staphynilidae $(A) *$ & 1 & --- & --- & --- & --- & -- & --- & --- \\
\hline & Nitidulidae (A) * & --- & -- & --- & --- & 1 & --- & --- & --- \\
\hline & Scirtidae (L) & --- & -- & --- & -- & 1 & -- & --- & --- \\
\hline & Coleoptera sp. ${ }^{*}$ & --- & 1 & 0.32 & 1 & -- & --- & --- & --- \\
\hline & Athericidae $(\mathrm{L})$ & -1 & 0.57 & 0.45 & 1 & -1 & -1 & -1 & --- \\
\hline \multirow[t]{12}{*}{ Diptera } & Muscidae (L) & -- & 1 & --- & 1 & 1 & --- & -- & --- \\
\hline & Simuliidae (L) & -0.70 & -0.20 & -0.80 & -0.30 & 1 & -1 & -1 & -0.50 \\
\hline & Empididae (L) & -1 & -1 & -1 & -1 & -1 & -1 & -1 & 1 \\
\hline & Paratrichocladius sp. & -0.30 & 1 & -1 & -0.70 & 0.68 & -1 & -1 & -1 \\
\hline & Parapsectocladius sp. & -1 & -- & --- & -- & -1 & -1 & -1 & -1 \\
\hline & Pseudochironomus sp. & --- & --- & --- & -1 & -1 & -1 & -1 & --- \\
\hline & Thienemanniella sp. & 1 & -1 & -- & -1 & -- & -1 & -1 & -1 \\
\hline & Orthocladius sp. & 1 & --- & -1 & --- & --- & -1 & --- & --- \\
\hline & Lopescladius sp. & --- & -1 & --- & -1 & --- & 1 & -- & -1 \\
\hline & Ceratopogonidae sp. & -- & -- & -1 & -1 & -1 & -1 & -- & -1 \\
\hline & Pupae sp. & 1 & & & & 1 & & & \\
\hline & Adult sp.* & 1 & 1 & 1 & & 1 & & 1 & \\
\hline Odonata & Cyanallagma interruptum & --- & -- & 1 & --- & --- & --- & --- & --- \\
\hline Homoptera & Homoptera sp.* & 1 & 1 & & & & & 1 & \\
\hline Hymenoptera & Hymenoptera sp.* & 1 & & & & & & 1 & 1 \\
\hline Orthoptera & Orthoptera sp.* & & & & & & & 1 & \\
\hline Hemiptera & Hemiptera sp.* & -- & -- & --- & --- & --- & --- & 1 & --- \\
\hline Fish fragment & Eggs & & & 1 & & & & & \\
\hline
\end{tabular}

From Nant y Fall (NyF) and Cabeza de Vaca (CVA) streams (Patagonia, Argentina) during the study period (early autumn, late winter, late spring of 2005, and late summer of 2006). Taxa absence at both environment and trout stomach were represented by --- and terrestrial prey $\left(^{*}\right)$.

\section{Discussion}

Benthos density and composition varied seasonally and in a different way at both streams. Whereas at NyF, the highest benthos density occurred in early autumn, and at CVA, it occurred in late summer. This difference between streams is in line with observations by Miserendino and Pizzolón (2003, 2004), who documented at other Patagonian mountain rivers that macroinvertebrate diversity and density vary mainly due to environmental factors such as current speed and water temperature which differed between both streams. NyF was the most productive stream in terms of invertebrate density which results in a higher food availability for trouts. This agrees with the fact that lake-outlet streams, like NyF, are considered highly productive environments (Huryn and Wallace 2000; Brand and Miserendino 2012) and that the presence of patches of native forest upstream of the sampling site (Brand and Miserendino 2012) may help to buffer negative impacts on the structure of the invertebrate community related to the land-use activities there (Sponseller et al. 2001).
Overall, diet composition was dominated by Trichoptera species. These preys contributed strongly to the diet in late summer and early autumn in $\mathrm{NyF}$ and in late spring and summer in CVA, decreasing their importance as prey in the remaining seasons. Despite of the overall dominance of these species, the composition of the diet varied seasonally as observed in previous studies carried out in the region (Buria et al. 2009; Di Prinzio and Casaux 2012; Di Prinzio et al. 2013). Rainbow trouts from both streams tended to forage on the larger individuals of each prey species. Similarly, Buria et al. (2007) observed that at other three Patagonian streams, trouts foraged on the largest size classes of each prey species. According to Wissing and Hasler (1971), McCauley et al. (1974), and Rodgers and Qadri (1977), it seems that certain Trichoptera species contain more calories per gram than most of the macroinvertebrate taxa found in streams, and this could explain for the observed pattern in the diets of the analyzed specimens.

The diversity and width of the rainbow trout diet observed in this study is similar to that reported for this 
Table 4 Selectivity index (Ivlev) of body size prey $(\mathrm{mm})$ in the diet of rainbow trout (Oncorhynchus mykiss)

\begin{tabular}{|c|c|c|c|c|c|c|c|c|c|c|c|}
\hline \multicolumn{6}{|l|}{ Early autumn } & \multicolumn{6}{|l|}{ Late winter } \\
\hline \multicolumn{3}{|l|}{$\overline{N y F}$} & \multicolumn{3}{|l|}{ CVA } & \multicolumn{3}{|l|}{$\overline{\mathrm{NyF}}$} & \multicolumn{3}{|l|}{ CVA } \\
\hline & Size & Ivlev & & Size & Ivlev & & Size & Ivlev & & Size & Ivlev \\
\hline \multirow[t]{3}{*}{$\begin{array}{l}\text { Chilina } \\
\text { patagonica }\end{array}$} & S 4.87 & 1 & Chilina patagonica & S 4.87 & 1 & Hyalella araucana & S 2.85 & -1 & $\begin{array}{l}\text { Aubertoperla } \\
\text { illiesi }\end{array}$ & S 2.05 & -1 \\
\hline & M 9.74 & --- & & M 9.74 & --- & & M 5.70 & -0.89 & & M 4.10 & -0.76 \\
\hline & L 14.61 & -1 & & L 14.6 & -1 & & L 8.55 & -0.77 & & L 6.15 & -0.09 \\
\hline \multirow[t]{3}{*}{$\begin{array}{l}\text { Hyalella } \\
\text { araucana }\end{array}$} & S 2.22 & 1 & Antactoperla michaelseni & S 3.34 & -0.44 & Aubertoperla illiesi & S 1.78 & -1 & $\begin{array}{l}\text { Meridialaris } \\
\text { chiloeense }\end{array}$ & S 2.47 & -1 \\
\hline & M 4.44 & -0.37 & Antactoperla michaelseni & M 6.68 & 0.59 & & M 3.56 & -0.96 & & M 4.94 & -0.95 \\
\hline & L 6.66 & 1 & & L 10.02 & 0.51 & & L 5.34 & 0.68 & & L 7.41 & -0.65 \\
\hline \multirow[t]{3}{*}{$\begin{array}{l}\text { Notoperlopsis } \\
\text { femina }\end{array}$} & S 4.14 & -0.75 & Pelurgoperla personata & S 2.05 & -1 & $\begin{array}{l}\text { Limnoperla } \\
\text { jaffueli }\end{array}$ & S 2.6 & -1 & $\begin{array}{l}\text { Smicridea } \\
\text { annulicornis }\end{array}$ & S 3.65 & --- \\
\hline & M 8.28 & 0.43 & & M 4.10 & -0.95 & & M 4.72 & -0.94 & & M 7.30 & -0.82 \\
\hline & L 12.42 & 1 & & L 6.15 & 1 & & L 7.08 & 0.83 & & L 10.9 & 1 \\
\hline \multirow[t]{3}{*}{$\begin{array}{l}\text { Nousia } \\
\text { delicata }\end{array}$} & S 2.94 & -1 & Meridialaris chiloeense & S 2.67 & -1 & $\begin{array}{l}\text { Penaphlebia } \\
\text { chilensis }\end{array}$ & S 2.87 & -1 & Simuliidae & S 2.00 & -1 \\
\hline & M 5.88 & 0.58 & & M 5.34 & -0.96 & & M 5.74 & -1 & & M 4.00 & -0.91 \\
\hline & L 8.82 & 1 & & L 8.01 & -0.72 & & L 8.61 & -0.14 & & L 6.00 & -0.56 \\
\hline \multirow[t]{3}{*}{$\begin{array}{l}\text { Andesiops } \\
\text { torrens }\end{array}$} & S 2.05 & -0.22 & Andesiops torrens & S 2.45 & --- & $\begin{array}{l}\text { Parasericostoma } \\
\text { ovale }\end{array}$ & S 3.42 & -1 & Paratrichocladius & S 1.78 & -- \\
\hline & M 4.10 & -0.03 & & M 4.90 & --- & & M 6.84 & 0.05 & & M 3.56 & -- \\
\hline & L 6.15 & 1 & & L 7.35 & -0.68 & & L 10.2 & 0.71 & & L 5.34 & 0.91 \\
\hline \multirow{3}{*}{$\begin{array}{l}\text { Parasericostoma } \\
\text { ovale }\end{array}$} & S 2.94 & -0.95 & Parasericostoma ovale & S 2.14 & --- & Athericidae & S 4.45 & --- & & & \\
\hline & M 5.88 & -0.14 & & M 4.28 & --- & & M 8.90 & -0.78 & & & \\
\hline & L 8.82 & -0.21 & & L 6.42 & -0.92 & & L 13.3 & 1 & & & \\
\hline \multirow{3}{*}{$\begin{array}{l}\text { Hudsonema } \\
\text { flaminii }\end{array}$} & $\mathrm{S} 1.40$ & --- & Hudsonema flaminii & S 2.22 & -0.97 & Simuliidae & S 2.31 & --- & & & \\
\hline & M 2.80 & -0.60 & & M 4.44 & -0.85 & & M 4.62 & 0.83 & & & \\
\hline & L 4.20 & -0.25 & & L 6.66 & -0.35 & & L 6.93 & 1 & & & \\
\hline \multirow[t]{3}{*}{ Brachysetodes sp. } & S 1.29 & --- & Brachysetodes sp. & S 1.65 & -0.61 & & & & & & \\
\hline & M 2.58 & 0.21 & & M 3.30 & -1 & & & & & & \\
\hline & L 10.68 & 1 & & L 15.2 & -1 & & & & & & \\
\hline \multirow[t]{3}{*}{ Simuliidae } & S 1.84 & -0.55 & Smicridea annulicornis & S 3.65 & -1 & & & & & & \\
\hline & M 3.68 & 0.37 & & M 7.30 & -0.88 & & & & & & \\
\hline & L 5.52 & 0.04 & & L 10.9 & 0.21 & & & & & & \\
\hline \multirow[t]{6}{*}{ Paratrichocladius } & S 1.78 & --- & Athericidae & S 4.20 & -1 & & & & & & \\
\hline & M 3.56 & -0.39 & & M 8.40 & -1 & & & & & & \\
\hline & L 5.34 & 4 & & L 12.6 & -0.87 & & & & & & \\
\hline & & & Simuliidae & S2.09 & -0.96 & & & & & & \\
\hline & & & & M 4.18 & -0.82 & & & & & & \\
\hline & & & & L 6.27 & -0.58 & & & & & & \\
\hline
\end{tabular}


Table 4 Selectivity index (Ivlev) of body size prey $(\mathrm{mm})$ in the diet of rainbow trout (Oncorhynchus mykiss)

\begin{tabular}{|c|c|c|c|c|c|c|c|c|c|c|c|}
\hline \multicolumn{6}{|l|}{ Late spring } & \multicolumn{6}{|l|}{ Late summer } \\
\hline \multicolumn{3}{|l|}{$\mathrm{NyF}$} & \multicolumn{3}{|l|}{ CVA } & \multicolumn{3}{|l|}{ NyF } & \multicolumn{3}{|l|}{ CVA } \\
\hline & Size & Ivlev & & Size & Ivlev & & Size & Ivlev & & Size & Ivlev \\
\hline \multirow[t]{3}{*}{$\begin{array}{l}\text { Hyalella } \\
\text { araucana }\end{array}$} & S 1.35 & --- & Chilina patagonica & S 1.34 & --- & $\begin{array}{l}\text { Andesiops } \\
\text { torrens }\end{array}$ & S 1.80 & -1 & $\begin{array}{l}\text { Chilina } \\
\text { patagonica }\end{array}$ & S 5.94 & --- \\
\hline & M 2.70 & -1 & & M 2.68 & --- & & M 3.60 & -0.61 & & M 11.8 & 1 \\
\hline & L 4.05 & 1 & & L 4.02 & -0.96 & & L 5.40 & 0.63 & & L 17.8 & -1 \\
\hline \multirow[t]{3}{*}{$\begin{array}{l}\text { Limnoperla } \\
\text { jaffueli }\end{array}$} & S 2.00 & --- & Brachysetodes sp. & S 1.91 & -1 & $\begin{array}{l}\text { Parasericostoma } \\
\text { ovale }\end{array}$ & S 2.77 & -1 & $\begin{array}{l}\text { Antactoperla } \\
\text { michaelseni }\end{array}$ & S 1.65 & --- \\
\hline & M 4.00 & 0.57 & & M 3.82 & -0.95 & & M 5.57 & -0.55 & & M 3.30 & -0.44 \\
\hline & L 6.00 & 0.57 & & L 5.73 & -0.65 & & L 8.31 & -0.55 & & L 4.95 & 1 \\
\hline \multirow[t]{3}{*}{$\begin{array}{l}\text { Penaphlebia } \\
\text { chilensis }\end{array}$} & S 4.31 & -069 & Smicridea annulicornis & S 4.47 & --- & $\begin{array}{l}\text { Smicridea } \\
\text { annulicornis }\end{array}$ & S 1.74 & --- & $\begin{array}{l}\text { Pelurgoperla } \\
\text { personata }\end{array}$ & S 1.78 & --- \\
\hline & M 8.62 & -0.67 & & M 8.94 & -0.16 & & M 3.48 & 0.85 & & M 3.56 & --- \\
\hline & L 12.9 & -1 & & L 13.4 & -0.16 & & L 5.22 & 0.85 & & L 5.34 & -0.95 \\
\hline \multirow{3}{*}{$\begin{array}{l}\text { Parasericostoma } \\
\text { ovale }\end{array}$} & S 3.74 & -0.75 & & & & & & & Nousia crena & S 2.27 & -1 \\
\hline & M 7.48 & 0.38 & & & & & & & & M 4.57 & -1 \\
\hline & L 11.2 & -0.87 & & & & & & & & L 6.81 & 0.60 \\
\hline \multirow[t]{3}{*}{ Smicridea annulicornis } & S 3.67 & 1 & & & & & & & Andesiops torrens & S 2.05 & --- \\
\hline & M 7.34 & --- & & & & & & & & M 4.10 & -1 \\
\hline & L 11.0 & -1 & & & & & & & & L 6.15 & 1 \\
\hline \multirow[t]{15}{*}{ Paratrichocladius sp. } & S 1.78 & --- & & & & & & & Hudsonema flaminii & S 2.14 & -1 \\
\hline & M 3.56 & -0.92 & & & & & & & & M 4.28 & --- \\
\hline & L 5.34 & -0.69 & & & & & & & & L 6.42 & 1 \\
\hline & & & & & & & & & Brachysetodes sp. & S 2.27 & -1 \\
\hline & & & & & & & & & & M 4.54 & -1 \\
\hline & & & & & & & & & & L 6.81 & -0.91 \\
\hline & & & & & & & & & $\begin{array}{l}\text { Neoatopsyche } \\
\text { brevispina }\end{array}$ & S 2.89 & -1 \\
\hline & & & & & & & & & & M 5.78 & -1 \\
\hline & & & & & & & & & & L 11.0 & -0.97 \\
\hline & & & & & & & & & Smicridea annulicornis & S 3.69 & -1 \\
\hline & & & & & & & & & & M 7.38 & -0.17 \\
\hline & & & & & & & & & & L 11.0 & 0.13 \\
\hline & & & & & & & & & Simuliidae & S 2.22 & -1 \\
\hline & & & & & & & & & & M 4.44 & -1 \\
\hline & & & & & & & & & & L 6.66 & 1 \\
\hline
\end{tabular}

From Nant y Fall (NyF) and Cabeza de Vaca (CVA) streams (Patagonia, Argentina) during the study period. Body size taxa absence was represented by ---. S, small size; $M$, medium size; $L$, large size.

species in other Patagonian environments (Arismendi et al. 2012; Di Prinzio et al. 2013) but higher than the observed in the native catfish Hatcheria macraei (Ferriz 1994, 2012; Barriga et al. 2009; Di Prinzio and Casaux
2012). This fact supports the proposal by Di Prinzio et al. (2013) indicating that the expansion success of the rainbow trout in Patagonia could be explained, among other factors, by their high feeding plasticity, which 

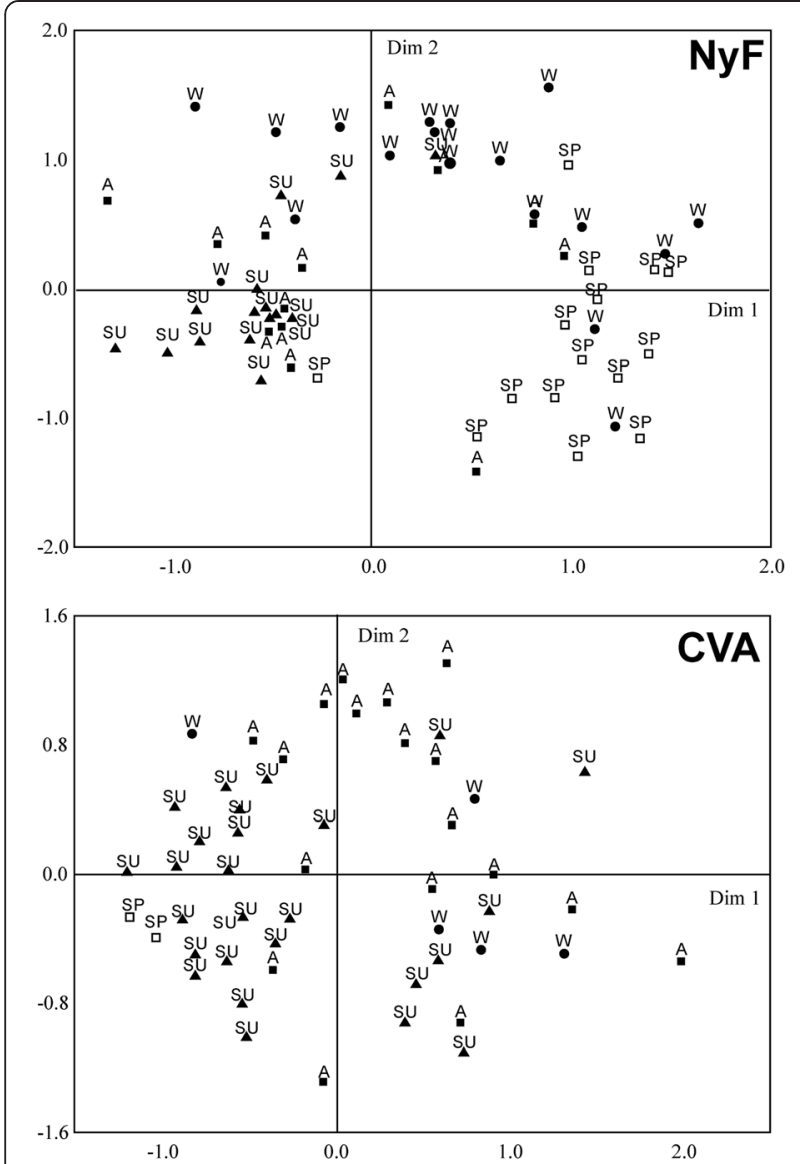

Figure 6 Results of the multidimensional ordination of Oncorhynchus mykiss. Based on stomach content data collected during the study period (early autumn, late winter, late spring 2005 and late summer 2006) at Nant y Fall (NyF) and at Cabeza de Vaca (CVA) streams (Patagonia Argentina). A, autumn; W, winter; SP, spring; SU, summer.

depends on different issues (prey-type characteristics, seasonal changes in resource supply, food-habitat utilization, etc.). This allows the trout to exploit temporarily abundant food resources and switch between specialized and generalized feeding strategies, buffering changes in food availability as observed in some streams in Patagonia (Di Prinzio et al. 2013).

Although prey selectivity varied seasonally, rainbow trout positively selected both aquatic (Gasteropoda, Crustacea, Plecoptera, Trichoptera, Ephemeroptera, Coleoptera, Diptera, and Odonata) and terrestrial organisms (adult dipteran, Oligochaeta, Araneae, Homoptera, Hymenoptera, Orthoptera, and Hemiptera), which is in line with other studies carried out in the area (Buria et al. 2009; Di Prinzio and Casaux 2012; Di Prinzio et al. 2013). Compared to CVA, at NyF, rainbow trouts positively selected a higher number of terrestrial species (Table 3). This difference between streams in the number of terrestrial prey selected could be explained, to some extent, by the higher riparian and littoral invertebrate richness registered at NyF (Miserendino et al. 2011). During late winter, trouts at NyF positively selected fish eggs. According to the egg size, these come from the rainbow trout spawning individuals who evidence that this trout auto-regulate, to some extent, their populations. On the other hand, some infaunal invertebrates like Oligochaeta and some small larvae of Coleoptera and Diptera (mainly Chironomidae) were not selected by trouts. This could be related, among other reasons, to the fact that trouts rely predominantly on visual cues to detect prey (Wilzbach et al. 1986; Angradi and Griffith 1990). For instance, compared drifting preys, McIntosh (2000) observed at New Zealand streams few oligochaetes in the diet of salmonid species.

The effects of the introduction of freshwater fish species are a matter of ongoing debate worldwide (Gozlan 2008, 2009; Leprieur et al. 2009; Gozlan et al. 2010). Unfortunately, the scarcity of biological data from the basins before and after the introduction prevents to clearly visualize which are the consequences and impacts of these actions. Frequently, introduced rainbow trouts and prey interaction results are unpredictable because the introduction is achieved in disturbed environments as those studied here. Moreover, fish can also have important effects on different levels of the ecosystems (Power 1992; Nyström et al. 2001; Townsend 2003). In this sense, it was observed at several countries, included Argentina, that fish introductions resulted in the elimination/reduction/alteration of native populations of both vertebrates and invertebrates (Flecker and Townsend 1994; Arismendi et al. 2009; McIntosh 2000; Di Prinzio and Casaux 2012; among others). Despite of the problems associated to the rainbow trout introduction, this fish is an emblematic species for sport fishing being this recreative activity an important source of incomes in the region. For being economically and ecologically sustainable, the administration of this activity requires an adequate knowledge on the species biology and on the prey-predator pattern, so this type of study helps to design mitigation and conservation guidelines because it encompasses not only the fish population but also the macroinvertebrate community and their biological interactions.

\section{Conclusions}

Our study reflects a dominance of trichopteran species in the rainbow trout diet. The fact that certain Trichoptera species contain more calories per gram than most of the macroinvertebrate taxa found in these streams could explain the observed pattern in the diets of the trout analyzed. The composition of the diet of the exotic trout varied seasonally. In both streams, rainbow trouts consumed the largest preys available in the environment and positively selected both aquatic and terrestrial preys. 


\section{Additional file}

Additional file 1: Mean contribution per habitat (density) of main benthic species per season at NyF and CVA streams. P, pools; $R$ riffles. Items found in trout stomachs at corresponding months are marked in gray.

\section{Competing interests}

The authors declare that they have no competing interests.

\section{Authors' contributions}

CYDP, GO, MLM, and RC participated in the field trips carried out environmental characterization. GO and MLM carried out the benthos sampled and benthos processed in laboratory. CYDP and RC carried out the fish sampled in the field. CYDP processed the fish material in laboratory and wrote the manuscript. RC made intellectual contributions and reviewed the manuscript. All authors read and approved the final manuscript.

\section{Acknowledgements}

We would like to thank Dra. Cecilia Brand for fieldtrip assistance and Dr. Miguel Archangelsky for fieldtrip assistance and for helpful comments on the English style. Thanks to anonymous reviewers for valuable comments that greatly improved the manuscript. This research was partially financed by the CONICET and PADI Foundation. This is Scientific Contribution $\mathrm{n}^{\circ}$ 109 from LIESA.

\section{Author details}

${ }^{1}$ Consejo Nacional de Investigación en Ciencia y Tecnología (CONICET), Rivadavia 1917, 1033 Buenos Aires, Argentina. ${ }^{2}$ Centro de Investigaciones Esquel de Montaña y Estepa Patagónica (CIEMEP), Sarmiento 890, 9200 Esquel, Argentina. ${ }^{3}$ Laboratorio de Investigación en Ecología y Sistemática Animal (LIESA), Universidad Nacional de la Patagonia, Sarmiento 890, 9200 Esquel, Argentina. ${ }^{4}$ Instituto Antártico Argentino, Cerrito 1248, 1010 Buenos Aires, Argentina.

Received: 16 July 2014 Accepted: 19 January 2015

Published online: 06 February 2015

\section{References}

Albariño RJ, Buria LM (2011) Altered mayfly distribution due to strong interactions with alien rainbow trout in Andean streams of Patagonia. Limnologica 41:220-227

Allan JD (1978) Trout predation and the size composition of the stream drift. Limnol Oceanog 23:1231-1237

Angradi TR, Griffith JS (1990) Diel feeding chronology and diet selection of rainbow trout (Oncorhynchus mykiss) in the Henry's Fork of the Snake River. Idaho Can J Fish Aquat Sci 47:199-209

APHA (1994) Standard methods for the examination of water and wastewater. American Public Health Association, Hanover MD, p 70

Arismendi I, Soto D, Penaluna B, Jara C, Leal C, León-Muñoz J (2009) Aquaculture, non-native salmonid invasions and associated declines of native fishes in Northern Patagonian lakes. Freshwater Biol 54(5):1135-1147, doi:10.1111/j.1365-2427.2008.02157.x

Arismendi I, Gonzalez J, Soto D, Penaluna B (2012) Piscivory and diet overlap between two non-native fishes in southern Chilean streams. Austral Ecol 37:346-354

Baigun C, Ferriz RA (2003) Distribution patterns of freshwater fishes in Patagonia (Argentina). Org Divers Evol 3:151-159

Barriga JP, Battini MA (2009) Ecological significances of ontogenetic shifts in the stream-dwelling catfish, Hatcheria macraei (Siluriformes, Trichomycteridae), in a Patagonian river. Ecol Freshw Fish 18(3):395-405, doi:10.1111/j.16000633.2009.00356.x

Baxter CV, Fausch KD, Murakami M, Chapman PL (2004) Fish invasion restructures stream and forest food webs by interrupting reciprocal prey subsidies. Ecology 85:2656-2663

Bisson JD (1978) Trout predation and the size-composition of stream drift. Limnol Oceanogr 23:1231-1237

Brand C, Miserendino ML (2012) Life cycle phenology, secondary production, and trophic guilds of caddisfly species in a lake-outlet stream of Patagonia. Limnologica 42:108-117
Buria L, Albariño R, Díaz Villanueva V, Modenutti B, Balseiro E (2007) Impact of exotic rainbow trout on the benthic macroinvertebrate community from Andean-Patagonian headwater streams. Fundam Appl Limnol 168:145-154

Buria LM, Albariño RJ, Modenutti BE, Balseiro EG (2009) Temporal variations in the diet of the exotic rainbow trout (Oncorhynchus mykiss) in an Andean-Patagonian canopied stream. Rev Chil Hist Nat 82:3-15

Buria L, Albariño R, Díaz Villanueva V, Modenutti B, Balseiro E (2010) Does predation by the introduced rainbow trout cascade down to detritus and algae in a forested small stream in Patagonia? Hydrobiologia 651:161-172

Clarke KR, Warwick RM (1994) Change in marine communities: an approach to statistical analysis and interpretation. Natural Environment Research Council, UK

Coronato FR, Del Valle HF (1988) Caracterización hídrica de las cuencas hidrograficas de la provincia del Chubut. Publicación Técnica, Cenpat-Conicet, Chubut, Puerto Madryn, p 184

Di Prinzio CY, Casaux RJ (2012) Dietary overlap among native and non-native fish in Patagonian low-order streams. Ann Limnol-Int J Lim 48:21-30

Di Prinzio CY, Casaux RJ, Miserendino ML (2009) Effects of land use on fish assemblages in Patagonian low order streams. Ann Limnol-Int J Lim 45:267-277

Di Prinzio CY, Miserendino ML, Casaux R (2013) Feeding strategy of the non-native rainbow trout, Oncorhynchus mykiss, in low-order Patagonian streams. Fisheries Manag Ecol 20:414-425

Domínguez E, Fernández HR (eds) (2009) Macroinvertebrados bentónicos sudamericanos. Sistemática y biología. Fundación Miguel Lillo, Tucumán, Argentina

Ferriz RA (1994) Diet of Olivaichthys viedmensis (Mac Donagh, 1931) and Hatcheria macraei (Girard, 1855) (Teleostei, Siluriformes) in the Limay River, Argentina. Nat Patag Cinc Biol 2:83-88

Ferriz RA (2012) Diet of Hatcheria macraei (Girard, 1855) (Teleostei, Siluriforms, Trichomycteridae) in the Chubut River, Argentina. Lat Am J Aquat Res 40(1):248-252

Flecker AS, Townsend CR (1994) Community-wide consequences of trout introductions into New Zealand streams. Ecol Appl 44:798-807

Forrester GE, Chase JG, McCarthy W (1994) Diel and density-related changes in food consumption and prey selection by brook charr in a New Hampshire stream. Environ Biol Fish 39:301-311

Gordon ND, McMahon TA, Finlayson BL (1994) Stream hydrology, an introduction for ecologists. Wiley and Sons, New York. pp, 444

Gotelli NJ, Ellison AM (2005) A primer of ecological statistics. Sinauer Associates Inc. Publishers, Sunderland, Massachusetts, U.S. A, p 510

Gozlan RE (2008) Introduction of non-native freshwater fish: is it all bad? Fish Fish 9:106-115

Gozlan RE (2009) Response by R Gozlan - biodiversity crisis and the introduction of non-native fish: solutions, not scapegoats. Fish Fish 10:109-110

Gozlan RE, Britton JR, Cowx I, Copp GH (2010) Current knowledge on non-native freshwater fish introductions. J Fish Biol 76:751-786

Hureau J (1970) Biologie comparee de quelques poissons antarctiques (Nototheniidae). Bull Inst Oceanogr 68:1-244

Huryn AD, Wallace JB (2000) Life history and production of stream insects. Ann Rev Entomol 45:83-110

Ivlev VS (1961) Experimental ecology of the feeding of fishes. Yale University Press, New Haven, CT \& London, p 302

Johnson RK, Hering D, Furse MT, Clarke RT (2006) Detection of ecological change using multiple organism groups: metrics and uncertainty. Hydrobiologia 566(1):115-137

Krebs CJ (1989) Ecological methodology. Harper Collins Publishers, New York, p 652

Leprieur F, Brosse S, García-Berthou E, Oberdorff T, Olden JD, Townsend CR (2009) Scientific uncertainty and the assessment of risks posed by non-native freshwater fishes. Fish Fish 10:88-97

Levins R (1968) Evolution in changing environments: some theoretical explorations. Princeton University Press, Princeton, NJ, p 132

Ludwing JA, Reynolds JF (1988) Statistical Ecology. Wily Interscience, New York

Macchi PJ, Cussac VE, Alonso MF, Denegri MA (1999) Predation relationships between introduced salmonids and the native fish fauna in lakes and reservoirs in northern Patagonia. Ecol Freshw Fish 8:227-236

Marshall S, Elliott M (1997) A comparison of univariate and multivariate numerical and graphical techniques for determining inter and intraspecific feeding relationships in estuarine fish. J Fish Biol 51:526-545 
McCauley VJE, Tsumura K (1974) Calorific values of Chironomidae (Diptera). Can J Zool 52:581-586

McIntosh AR (2000) Aquatic predator-prey interactions. In: Collier KJ, Winterbourn MJ (eds) New Zealand stream invertebrates: ecology and implications for management. New Zealand Limnological Society, Hamilton, New Zealand

Miserendino ML, Pizzolón LA (2003) Distribution of macroinvertebrates assemblages in the Azul-Quemquemtreu river basin, Patagonia, Argentina. New Zeal J Mar Fesh 37:525-539

Miserendino ML, Pizzolón LA (2004) Interactive effects of basin features and land-use change on macroinvertebrate communities of headwater streams in the Patagonian Andes. River Res Appl 20:967-983

Miserendino ML, Casaux R, Archangelsky M, Di Prinzio CY, Brand C, Kutschker AM (2011) Assessing land-use effects on water quality, in-stream habitat, riparian ecosystems and biodiversity in Patagonian northwest streams. Sci Total Environ 409(3):612-624, doi:10.1016/j.scitotenv.2010.10.034

Modenutti BE, Balseiro EG (1994) Zooplankton size spectrum in four lakes of the Patagonian Plateau. Limnologica 24:51-56

Nakano S, Fausch KD, Kitano S (1999) Flexible niche partitioning via a foraging mode shift: a proposed mechanisms for coexistence in stream-dwelling charrs. J Anim Ecol 68:1079-1092

Newman RM, Waters TH (1984) Size-selective predation on Gammarus pseudolimnaeus by trout and sculpins. Ecology 65:1535-1545

Nyström P, Svensson O, Lardner B, Brönmark C, Granéli W (2001) The influence of multiple introduced predators on a littoral pond community. Ecology 82:1023-1039

Osenberg CW, Mittelbach GG (1996) The relative importance of resource limitation and predator limitation in food chains. In: Polis GA, Winemiller KO (eds) Food webs: integration of patterns and dynamics. Chapman \& Hall, New York, New York, USA, pp 134-148

Osenberg CW, Sarnelle O, Cooper SD, Holt RD (1999) Resolving ecological questions through meta-analysis: goals, metrics, and models. Ecology 80(4):1105-1117

Pascual M, Macchi P, Urbanski J, Marcos F, Riva Rossi C, Novara M, Dell'Arciprete P (2002) Evaluating potential effects of exotic freshwater fish from incomplete species presence-absence data. Biol Inv 4:101-113

Peckarsky B (1982) Aquatic insect predatory-prey relations. Bioscience 32(4):261-265

Power ME (1992) Top-down and bottom-up forces in food webs: do plants have primacy? Ecology 73:733-746

Ringler NH (1979) Selective predation by drift feeding brown trout (Salmo trutta). J Fish Res Board Can 36:392-403

Rodgers DW, Qadri SU (1977) Seasonal variations in calorific values of some littoral benthic invertebrates of the Ottawa River, Ontario. Can J Zool 55:881-884

Sih A (1987) Predators and prey lifestyles: an evolutionary and ecological overview. In: Kerfoot WC, Sih A (eds) Predation: direct and indirect impacts on aquatic communities. University Press of New England, Hanover, pp 203-224

Sokal RR, Rohlf FJ (1995) Biometry, 3rd edn. W.H. Freeman and Company, New York, USA

Sponseller RA, Benfield EF, Valett HM (2001) Relationships between land use, spatial scale and stream macroinvertebrate communities. Freshwater Biol 46:1409-1424

Stephens DW, Krebs JR (1986) Foraging theory. Princeton University Press, Princeton

Townsend CR (2003) Individual, population, community, and ecosystem consequences of a fish invader in New Zealand streams. Conserv Biol 17:38-47

Wesner JS (2012) Predator diversity effects cascade across an ecosystem boundary. Oikos 121:53-60

Wilzbach ME, Cummins KW, Hall JD (1986) Influence of habitat manipulations on interactions between cutthroat trout and invertebrate drift. Ecology 67:898-911

Wissing TE, Hasler AD (1971) Intraseasonal change in caloric content of some freshwater invertebrates. Ecology 52:371-373

Wooster D (1994) Predator impacts on stream benthic prey. Oecologia 99:7-15

Zaret TM (1980) Predation and freshwater communities. Yale University Press, New Haven, CT

\section{Submit your manuscript to a SpringerOpen ${ }^{\circ}$ journal and benefit from:}

- Convenient online submission

- Rigorous peer review

- Immediate publication on acceptance

- Open access: articles freely available online

- High visibility within the field

- Retaining the copyright to your article

Submit your next manuscript at $\gg$ springeropen.com 